\title{
Innovation Strategy of Cosmetic Packaging Design Made of Bamboo
}

\author{
Nanda N. Anggalih* \\ Universitas Negeri Surabaya, Indonesia \\ "Corresponding author. Email nandaanggalih@unesa.ac.id
}

\begin{abstract}
Bamboo has been talked about a lot by international communities in the world eco-label, specifically because it has big potential to be used as a sustainable material. As the third biggest country to produce bamboo globally, Indonesia has been supporting the regulation to establish bamboo nationally. The increase of beauty trends is followed by the rise of cosmetic's packaging waste. The packages have the potential to be substituted by other eco-friendly materials because the main function is as the container. This study aims to reduce waste using an abundant renewable source in Indonesia by exploring the innovation strategy of cosmetic packaging design made of bamboo. The methodology of this study is qualitative, followed by packaging design planning using a design thinking approach. The result of the planning is seven designs products which include primer packaging and secondary packaging. It is implemented based on the ability of the local craftsmen after the observation. Further study is needed to discover how far the packaging which has been designed can be executed by bamboo craftsmen using the ability they have mastered.
\end{abstract}

Keywords: Packaging, Bamboo, Cosmetic.

\section{INTRODUCTION}

Bamboo has been talked about a lot by international communities in the world eco-label. Many forums have been conducted to study every aspect of bamboo. Indonesia is the third biggest country to produce bamboo in the world [1]. It has been part of the culture for a long time and used a lot for many needs such as furniture, home appliance, transportation tool, and many other conditions include packaging. The Indonesian government, through the ministry of industry, has officially supported the national bamboo development policy. It has been declared in the forum of national bamboo development in Jakarta on October 23rd, 2012. It is because bamboo has high potential to be used as a sustainable material, namely relatively easy to obtain, easy to grow, year-round stock availability, and many craftsmen in Indonesia.

Generally, the primary function of packaging is to protect the product from any damages and promotions devices [2]. To increase the product's attractiveness to the consumers, the packaging is made with a distinctive shape and appearance to advertise or add the value of the product. However, it is executed with an exaggerated package or over-pack. The purpose is to make the product looks fancy, efficient, and so on. It is unnecessary and harms nature. In the cosmetic and pharmaceutical packaging field, one of the most used plastic materials is polyethylene (PE), a thermoplastic resin obtained by polymerization of ethylene [3]. Therefore, the action to reduce the packaging and replace the material can be done to avoid further waste and environmental damage. The reduction can be lessening the thickness of the material or the size of the package, developing the quality of the plastic that can be broken down naturally, and using renewable sources (sustainable).

Cosmetic packaging has the potential for material development. It is also can be substituted by using sustainable material that is bamboo. Plastic packaging in the cosmetic product has a less complicated function than food and beverages packages. Their functions are to protect the foods from sunlight, air, odor contamination, and other substances. It is also to make the products last longer. While on the cosmetic product, the package requirement is considerably simpler. The additional preservation substance in the cosmetic will make it last longer [4] even after being unboxed compared to food and beverages. The level of contamination to cosmetics is low. Thus it is possible to be replaced by other materials such as bamboo. 
Furthermore, these are following descriptions of the potential development of cosmetic packaging with bamboo material: 1) The bamboo packaging aims to cosmetics functions either as a container or secondary packaging, 2) as secondary packaging, the bamboo has a low level of contamination so that it can be used approximately in two years after opening the product, 3 ) it can be used repeatedly through refills, 4) the bamboo material has characteristics and uniqueness when it is developed for cosmetic products so that they have a high value, 5) it can reduce excessive use of plastic materials, and 6) it has a good innovation with government support to develop bamboo materials so that it is expected to be a solution or reduction of environmental damage.

According to the background descriptions above, it can be concluded that to reduce packaging waste, using renewable and naturally biodegradable materials can be carried out. In accordance with that fact, bamboo is a renewable material that fits the criteria. Moreover, this study is carried out in order to reduce plastic waste by utilizing renewable materials that are abundantly available in Indonesia, specifically through the exploration of cosmetic packaging design innovations with bamboo material. Therefore, this research is conducted and expected to support environmental empowerment efforts through the development of packaging designs made from renewable resources.

\section{METHODS}

The qualitative method and design thinking research approach were used in this study. The common feature of qualitative research is that they aim to create understanding from data as the analysis proceeds [5]. The method fits the goal of getting an optimal design throughout the iterative process. As the study goes, two kinds of data will be included, primary and secondary data. Primary data was obtained through field observation at Selaawi Sub-district of Garut District of West Java and by interviewing a bamboo artisan to know techniques that have been mastered and his skill, which aims to explore other new techniques. On the other hand, secondary data was obtained through desktop research and literature review related to the previous study about bamboo material developing techniques. Next, the design thinking method was used in the cosmetic packaging design process by following four stages, namely 1) empathy, 2) define, 3) ideate, and 4) prototype.

\section{RESULTS AND DISCUSSION}

\subsection{Analysis of Research Results}

The interview was conducted with three bamboo craftsmen who are located at Selaawi Sub-district of Garut District. Through interviews and field observation, it can be concluded that the craftsmen in Garut are much mastered the bamboo developing techniques for bird cages and baskets. However, the group of craftsmen wanted to develop new processing techniques shown by the researchers, namely coiling and bending the bamboo. The results of these techniques development produced the products with various characteristics such as bottles, vases, and glasses that can contain liquids (see Figure 1).

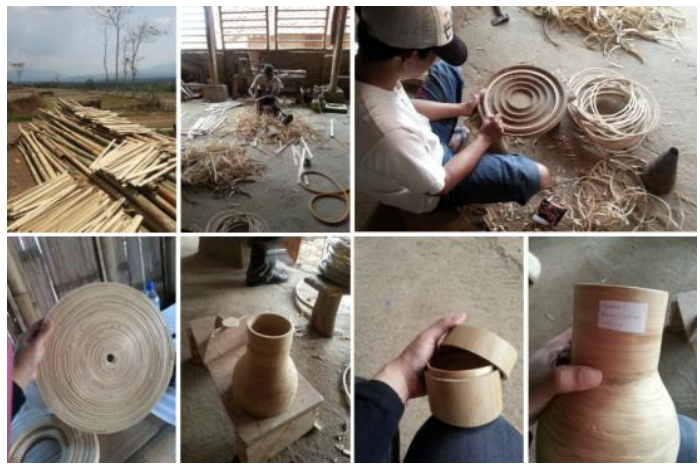

Figure 1 The technique of coiling and bending the bamboo made by craftsmen at Selaawi sub-district of Garut.

\subsection{Design Concept}

Empathise $\rightarrow$ Define $\rightarrow$ Ideate $\rightarrow$ Prototype

Figure 2 Design thinking method

The qualitative data was obtained through interviews and field observation. The method used in this research is the simplified form of the six process steps with iteration loops: understanding, observing, defining problems, finding ideas, developing prototypes, and testing [6]. The simple steps are shown in four stages. Figure 2 displays the four stages. This method was chosen in order to get the optimum design concept as following descriptions:

\subsubsection{Material}

Types of bamboo that can be used as a packaging material are as follows [7]: 1) Bambusa vulgaris, there are two types of this bamboo, namely light green stems with the straight stem and other stems which grow bent or curvy; 2) Dendrocalamus asper or pring betung, widely known as the large type of bamboo which can grow $26 \mathrm{~cm}$ in diameter and height of $25 \mathrm{~m}$ [8]. Both types of bamboo are very common and suitable for manufacturing wicker items, paper, particle of board, and furniture.

\subsubsection{Technique}

In this study, the author used the coiling technique and bending the bamboo. The coiling technique is processed by forming the bamboo stem into flat pieces, then put together and formed into blocks or boards, then glued and pressed [9]. Meanwhile, bending the bamboo is conducted by heating the bamboo material using hot 
steam or fire. Its goal is to straighten the bamboo stem so that it can form a curve.

\subsubsection{Visual Concept}

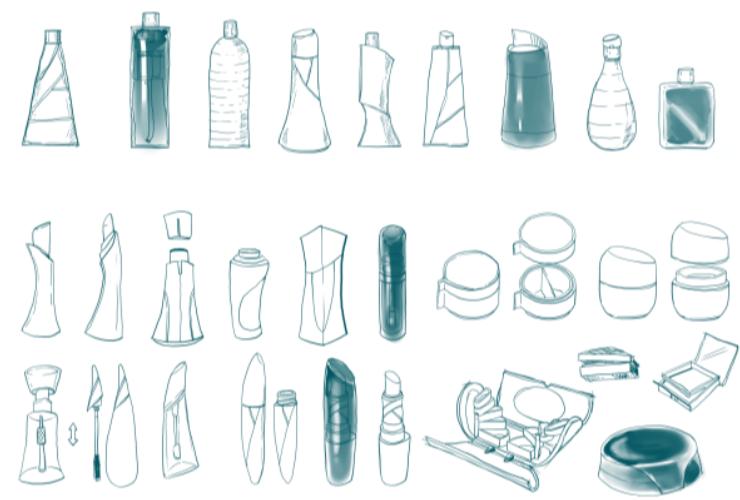

Figure 3 The design sketch of cosmetic packaging

The visual concept is developed using the design thinking approach. First, it made several sketches for each packaging category (see Figure 3 as the example of the design sketch). The next step is to choose one illustration or sketch from each category by considering the aspect of completeness of function and can be produced with the technique of coiling and bending the bamboo. Then, the selected sketch is developed in a detailed design.

\subsection{Design Implementation}

\subsubsection{Compact Powder}

Compact powder or compact powder packaging is designed in a minimalist way to be easy to carry and use. Primary packaging that is in direct contact with the product uses a plastic or metal layer to avoid contamination between the product and bamboo material that causes mildew changes, protects its contents, shelf life, and various other factors. Figure 4 displays the visualization of compact powder packaging.
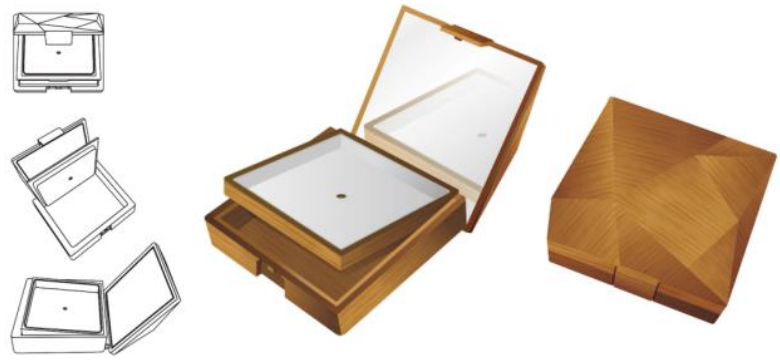

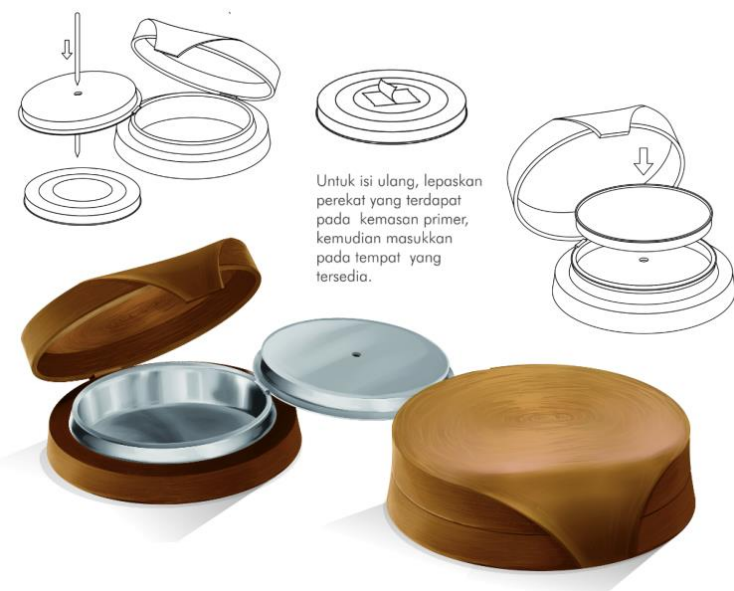

Figure 4 Visualization of compact powder packaging

\subsubsection{Dispenser}

This packaging is used for various products in liquid forms, such as shampoo, lotion, body oil, cleanser, etc. Due to its requirement to withstand multiple usages, laminated bamboo can improve durability. It was known that laminated bamboo has a better density compared to normal non-laminated bamboo [10]. Figure 5 shows the packaging visualization of a dispenser type.

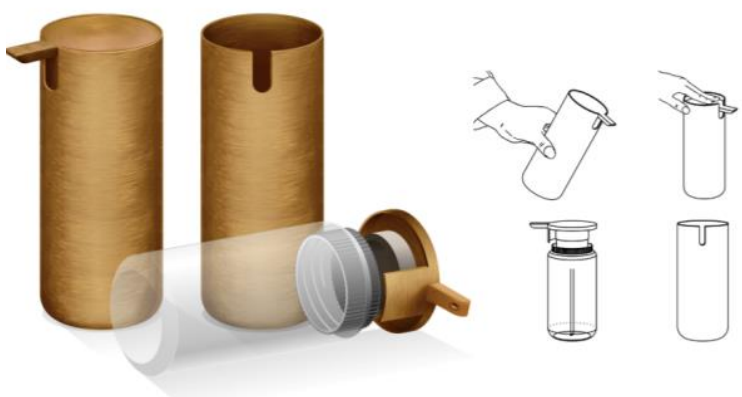

Figure 5 Packaging visualization of a dispenser type

\subsubsection{Tube}

This type of packaging can be used for cosmetic products in creams, such as night cream, foundation, body butter, body scrub, and so on. The main concept of this packaging is reusable packaging that can be reused to be refilled. However, when the user no longer wants it (for example, outdated or damaged parts), the packaging can be reused as a flower pot. At the bottom of the packaging, there is a cavity between the primary and secondary packaging (this is very common in cosmetic cream packaging) which can be used as a seedbed. Figure 6 displays the visualization of compact powder packaging. 


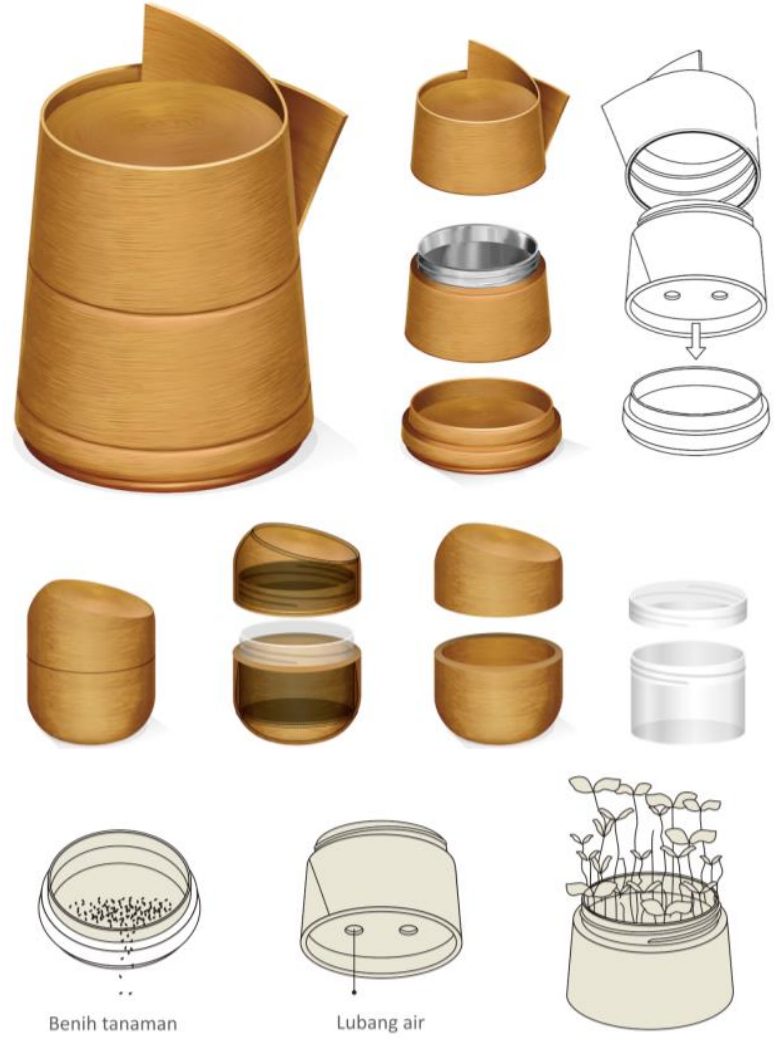

Figure 6 Visualization of compact powder packaging

\subsubsection{Disposable Packaging}

This type of packaging is only disposable and cannot be refilled because the products are quite complex, such as eye shadow, lipstick and mascara. Figure 7 displays disposable packaging visualization.

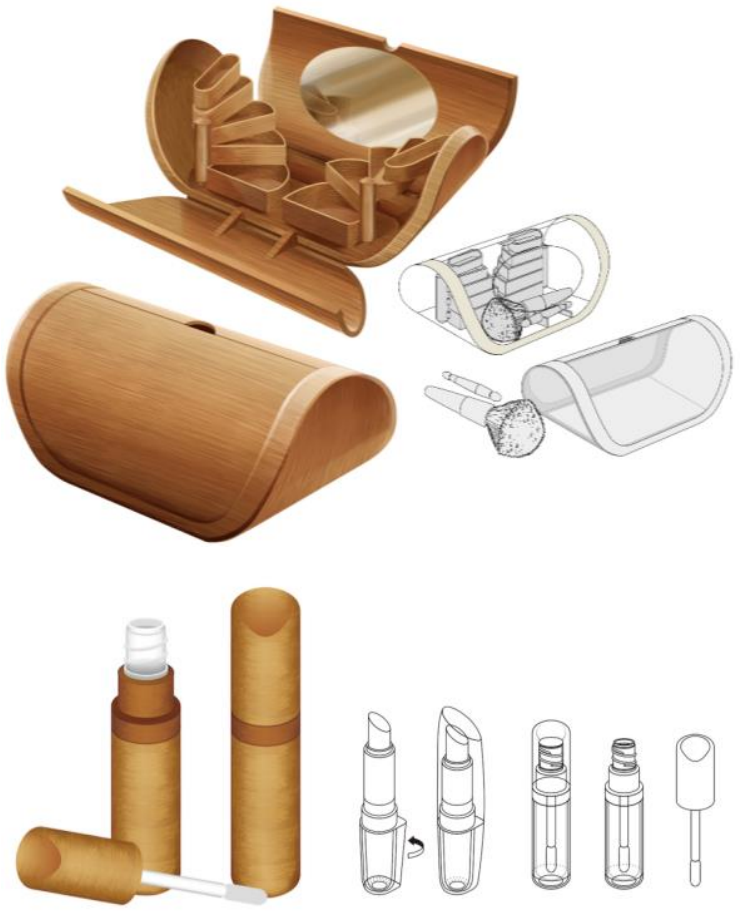

Figure 7 Disposable packaging visualization

\section{CONCLUSION}

Based on the results of this study and the discussion that has been explained in the previous chapters, the authors draw several conclusions, including the following:

First, less damaging and environmentally friendly packaging has more significant market potential because consumers are increasingly concerned about environmental problems caused by packaging that cannot be recycled. Second, compared to metal, plastic, and packaging paper, when a product is made from bamboo, it is considered more environmentally friendly because bamboo has a short growing life and grows in all seasons. Third, in the development of bamboo packaging in future studies, many stages of study are needed. One of them is it must pay attention to the skills of the craftsman so that the packaging can function properly.

Furthermore, in this design, there are still much that can be developed and considered for future research, such as: (1) The strategy for developing bamboo materials for various types of packaging requires laboratory testing to measure the feasibility of the material, the level of contamination, weather resistance, and so on. (2) Although this research explores packaging in the realm of concepts, it can be developed again to the prototyping stage in the future. (3) Empowerment of bamboo craftsmen is important, especially to teach society some new techniques they have not mastered.

\section{ACKNOWLEDGMENTS}

Thanks to Allah SWT, my husband who has supported the research, my parents, relatives, and colleagues who have helped in the process of this research.

\section{REFERENCES}

[1] M. Hantoro, and B. Mardiono, "Eksplorasi Desain Kemasan Berbahan Bambu sebagai Produk Oleholeh Premium dengan Studi Kasus Produk Makanan UKM Purnama Jati Jember," Jurnal Sains dan Seni ITS, vol.7, no. 1, pp. 68 2018, DOI: https://doi.org/10.12962/j23373520.v7i1.30041

[2] P. Gopinathar, G. Prabha and D.K. Ravichandran, "The Role of Packaging in Manufacturing-A Brief Understanding," IOSR J. Bus. Manage.(IOSR-JBM), vol. 18, no. 12, 2016.

[3] B. Briasco, P. Capra, A.C. Cozzi, B. Mannucci and P. Perugini, "Packaging evaluation approach to improve cosmetic product safety," Cosmetics, vol. 3, no. 3, pp. 32, 2016, DOI: https://doi.org/ 10.3390/ cosmetics 3030032

[4] N. Halla, I.P. Fernandes, S.A. Heleno, P. Costa, Z. Boucherit-Otmani, K. Boucherit, et al., "Cosmetics 
Preservation: A Review on Present Strategies," Molecules, vol. 23, no. 7, pp. 1571, 2018, DOI: https://doi.org/ 10.3390/molecules23071571

[5] J.W. Creswell, Research design: Qualitative and quantitative approaches. Thousand Oaks, CA: Sage, 1994.

[6] C. Müller-Roterberg, Handbook of Design Thinking, Publisher: Kindle Direct Publishing. ISBN: 978$1790435371,2018$.

[7] H. Nugraha, "Pengolahan Material Bambu dengan Menggunakan Teknik Laminasi dan Bending untuk Produk Furniture," Jurnal Universitas Pembangunan Jaya, vol. 1, pp. 2, ISSN: 2337-7313, 2014.

[8] M.W. Sutiyono, "Karakteristik Tanaman Bambu Petung (Dendrocalamus Asper Back.) di Dataran Rendah Di Daerah Subang, Jawa Barat," Prosiding Seminar Nasional VIII Biologi, vol. 8, no. 1, ISSN 2528-5742, 2011.

[9] A.S. Djariyah, Aneka Kerajinan Bambu. Yogyakarta: Kanisius, 2009.

[10] I. Dayadi, K.Y. Widiati, "Sifat Fisik dan Mekanik Bambu Laminasi Dari Jenis Bambu Betung (Dendrocalamus Asper) Dengan Perekat Pva," Prosiding Seminar Nasional Ke 1 Tahun 2017 Balai Riset dan Standardisasi Industri Samarinda, pp 8087, ISBN 987-602-51095-0-8, 2017. 